\title{
Realistic mathematics education (RME) approach for primary school students' reasoning ability
}

Dyah Worowirastri Ekowati, Universitas Muhammadiyah Malang

Figa Zulfi Azzaha, Universitas Muhammadiyah Malang Setiya Yunus Saputra, Universitas Muhammadiyah Malang

Beti Istanti Suwandayani $\bowtie$, Universitas Muhammadiyah Malang

\section{beti@umm.ac.id}

\begin{abstract}
The motive of this examination was to decide the impact of the RME method on college students' reasoning competencies in the two-dimensional material. A quantitative method became decided to chatter the type of pre-experimental studies with one institution pretest-posttest design. The populace of this examination became the fourthgrade college students of SD Muhammadiyah 3 Assalam Malang with a complete of sixteen college students. The data series used for this examination blanketed checks and documentation. The outcomes of this examination were received from the T-Test via the SPSS model 17. It confirmed the cost in the Sig. (2-tailed) the desk of 0.one hundred fifty wherein the cost became $>0.05$, so H1 became accepted. Analysis of the check supplied via a graph indicated that the RME method had a considerable impact on college students' reasoning competencies. The third indicator about the ability of students to compile and provide evidence of the accuracy of answers has increased significantly compared to other indicators. In general, it can be concluded that there is a significant effect of the Realistic Mathematics Education (RME) approach on the reasoning abilities of grade IV elementary school students.
\end{abstract}

Keywords: Realistic Mathematics Education, Reasoning, Primary School

Received 19 January 2021; Accepted 22 November 2021; Published 27 December 2021

Citation: Ekowati, D.W., Azzaha, F.Z., Saputra, S.Y., \& Suwandayani, B.I. (2021). Realistic mathematics education (RME) approach for primary school students' reasoning ability. Premiere Educandum : Jurnal Pendidikan Dasar dan Pembelajaran, 11(2), 269 - 279. Doi.org/10.25273/ pe.v11i2.8397

\section{(c) EY-NC-SA}

Published by Universitas PGRI Madiun. This work is licensed under the Creative Commons Attribution-NonCommercialShareAlike 4.0 International License. 


\section{INTRODUCTION}

Education can be obtained through formal and non-formal education. The basic level of formal education is primary school level education(Roqib, 2019). Students have to master all basic subjects set in the curriculum, such as mathematics. Regulations of The Minister of National Education No. 22 of 2006 (Malik, 2014) states that arithmetic topics want to accept to all college students beginning from the essential college degree to equip them with the capacity to assume creatively, critically, logically, and systematically (Ekowati et al., 2017).

In mathematics learning, students get new basic concepts that are abstract (Arsaythamby \& Zubainur, 2014; Basori, 2018). Therefore it is necessary to strengthen the understanding so that there are no misconceptions (Ekowati, 2017; Ekowati \& Suwandayani, 2020). Misconceptions often occur when students and educators incorrectly understand a mathematical concept (Burais et al., 2016). In mathematics learning, reinvention is expected; students can find a way to solve mathematics during learning (Ekowati et al., 2017). The most important thing for elementary school level students is if the discovery is something new that they have just discovered. This discovery method is considered a way to acquire knowledge by training students' intellectual abilities, such as thinking, reasoning, communicating, and problem-solving skills (Habibatul Izzah \& Azizah, 2019; Karabulut \& Özmen, 2018).

Mathematical know-how is shaped from how college students can reconstruct meaning and understand it so that know-how is not the simplest one from memorizing mathematical formulation and accepting fabric just like that (Saleh et al., 2018; Wood, 2012). National Council of Teachers of Mathematics (NCTM) reviews five basic mathematical abilities used as standards, namely problem-solving skills, reasoning skills, communication skills, connections, and representation (Nasongo et al., 2011; Siagian, 2016).

Reasoning is a crucial skill for gaining arithmetic knowledge (Firmanti, 2017; Fuadi et al., 2016). Suppose students' reasoning abilities cannot develop due to inappropriate learning methods. In that case, mathematics will become a subject that students will feel fear of since students will often be in a tedious phase by memorizing formulas and working on problems without understanding the meaning or implication of real life. (Saleh et al., 2018) suggest mathematical reasoning is the muse for the development of mathematical knowledge. This statement means that mathematical reasoning is the foundation or basis for building mathematical knowledge. Thus, educators who act as facilitators should be able to provide optimal facilities for students by helping to direct and develop their reasoning skills so that students can find ideas and build knowledge in mathematics (Firmanti, 2017; Nashihah et al., 2019). Below is the observation and interview data conducted in the initial research.

As a result of observations in November 2019, the researchers conducted interviews with the principal, classroom teachers, and fourth-grade students of SD Muhammadiyah 03 Assalam Malang. This school is classified as a new school, and this year is the fourth year the school was founded. Interestingly, even though this school has just been established, the implementation of learning tends to use cooperative learning (Pane \& Darwis Dasopang, 2017). In the teaching-learning process, most students work in groups(Ekowati et al., 2017). Besides, the learning approach applied already uses the authentic learning approach. According to Lombardi, the authentic learning approach is learning centered on the real world, facing complex problems, and finding solutions to activities based on case studies and problem-solving (Laurens et al., 2018). This approach has also influenced student learning outcomes (Gusmida \& Islami, 2017; Hidayati, 2013). These models and approaches make learning more enjoyable so that most fourth-grade students are more interested in learning, and they continue to try to learn the material that has just been taught (Herman et al., 2019). In connection with the description above, 
the researchers applied a different but coherent approach, namely a realistic mathematics education approach in mathematics subject with the flat shape area study (Noviani et al., 2017).

Various research results involving RME with various learning media can encourage students to learn mathematical activities. The results can be seen from improving students' cognitive learning achievement. It also shows that how RME combined with various learning media affects students' cognitive achievement is still limited (Fuadiah, 2013; Laurens et al., 2018). The use of RME also involves problems in learning mathematics that is interesting and challenging. Such problems in daily life ultimately lead to a quality learning process (Fuadiah, 2013; Obiarta et al., 2014). The learning process is a presentation of mathematics learning that challenges students' thinking processes through contexts related to their daily activities. Students will be actively involved in the learning process through situations of understanding the usefulness of mathematical activities, requiring mastery of mathematical concepts so that students will perform various mathematical abilities in solving mathematical problems. RME is a learning theory that comes from natural things or student experiences (Laurens et al., 2018; Noviani et al., 2017). This theory emphasizes the skills of thinking, reasoning, processing, discussing, and collaborating so that students can solve problems on their own. In the end, students can carry out mathematical activities to solve their daily life problems, both individually and in groups (Herman et al., 2019). The Mathematical activities are numbers, algebra, statistics, measurements, and geometry. The last material is geometry, mainly a closed twodimensional, is as the focus of this study.

This study will explain students' reasoning abilities which are influenced by the Realistic Mathematics Education (RME) approach. This research focused on the area of a two-dimensional topic. It was expected that this research could benefit the development of science in the field of elementary school level mathematics education in general (Fuadiah, 2013). In addition, readers can enrich references about mathematics learning that uses a realistic approach.

\section{A Realistic Mathematics Education Approach}

A realistic mathematics approach is an approach to learning mathematics in a real context, with mathematical problems encountered in daily (Laurens et al., 2018; Obiarta et al., 2014). The steps of Realistic Mathematics Education (RME) in learning in this study are as follows: 1) Understanding Contextual Issues, At this stage, the researcher gives a contextual problem to the students; then, the teacher asks the students to understand the problem. 2) Explaining Contextual Problems, This next stage is more directed to questionand-answer activities. Teachers can help students when a problem has not been fully understood or is experiencing difficulties. 3) Solving Contextual Problems, After students understand the teacher's problem, the teacher gives questions that are done individually. Students are asked to solve problems using various settlement models at this stage. 4) Comparing Answers, Next, after completing the given task, students are directed to discuss answers. At this stage, students can find out various ways that can be done to find a correct answer. 5) Summing up, In the final stage, students and the teacher draw an interesting conclusion from the results of the previous discussion.

\section{METHODS}

\section{Research Design}

This study implemented a quantitative research approach. The design of research used is experimental research one-group pretest-posttest design. Considering that only one class was studied, there was no comparison class (Creswell \& Clark, 2018a). In this type of research, the researchers provided a treatment, where the researchers administered a 
test before being given treatment (pre-test), then provided a test after giving a treatment (post-test) (Sugiyono, 2014). The research design is as shown in the following table.

TABLE 1. Research design

\begin{tabular}{rrr}
\hline $\mathrm{O}_{1}$ & $\mathrm{X}$ & $\mathrm{O}_{2}$ \\
\hline
\end{tabular}

Source (Sugiyono, 2014)

Notes:

$\mathrm{O}_{1} \quad$ : Pre-test

$\mathrm{X} \quad$ : Treatment (RME approach in learning)

$\mathrm{O}_{2} \quad$ : Post-test (after treatment)

Pretest (01) determines the initial ability by giving a test before being given treatment. At the same time, the posttest (02) is used to give a test after being given treatment. Treatment is treatment through a realistic mathematics education (RME) approach.

\section{Participants}

This research was conducted in fourth class third Assalam elementary school of Muhammadiyah of Malang. The participants are students. Have 16 students as the experimental class population. Sampling using probability sampling techniques, where each member of the population was given the same opportunity to become a sample (Sugiyono \& Republik Indonesia, 2010). The criteria for the participants in this study were 4th-grade elementary school students, age ten years old, male and female, and students who could accomplish addition and subtraction operations.

\section{Material}

Pretest and posttest questions are used as research test instruments. The applied indicators have the same form and content but different question items. To see the results of applying the learning approach to students. As the Director-General of Primary and Secondary Education Regulations Documents, there are indicators of reasoning ability that have to be achieved, and in this study, the indicators used following the needs of students are presented as follows.

TABLE 2. Reasoning ability indicators

\begin{tabular}{ll}
\hline No. & \multicolumn{1}{c}{ Reasoning Ability Indicators } \\
\hline 1. & $\begin{array}{l}\text { Ability to present mathematical statements whether spoken, written, pictures, and/or } \\
\text { diagrams }\end{array}$ \\
\hline 2. & Ability to perform mathematical manipulation \\
\hline 3. & Ability to compile and provide evidence of the correctness of solutions \\
\hline 4. & Ability to conclude a statement \\
\hline 5. & Ability to find patterns or traits to make generalizations \\
\hline
\end{tabular}

Sources: (Holisin, 2009; Saleh et al., 2018)

\section{Procedures}

The procedures of the research are (1) compiling indicators, (2) control class rating, (3) collecting data, (4) data analysis (pretest-posttest, normality test, reliability test, hypothesis test (paired sample t-test)), and (5) conclusion. Quantitative research data analysis was carried out to answer the problem formulated previously (Creswell \& Clark, 2018b). 


\section{Analysis Data}

The data analysis technique in this study used a statistical T-test through SPSS version 17 (Sugiyono, 2014). Data analysis techniques follow the test stages, namely pretest-posttest, normality test, reliability test, hypothesis test (paired sample t-test). Data analysis decision-making is based on probability if $<0.05$, then $\mathrm{H} 0$ is rejected, and if $>0.05$, then $\mathrm{H} 1$ is accepted. The t-test was carried out to determine the effect of RME on students' reasoning abilities, especially on the flat plane material in fourth class third Assalam Elementary School of Muhammadiyah of Malang.

\section{RESULTS}

Mathematics learning that is carried out using the Realistic Mathematics Education (RME) approach for students' reasoning abilities obtains the following research results.

\section{Pretest and Posttest Results}

The results of data analysis from the pretest and posttest related to the use of the RME approach for students' reasoning abilities are listed in table 1 below.

TABLE 1. The results of the pretest and posttest scores paired samples statistics

\begin{tabular}{llcccc}
\hline & Mean & N & Std. Deviation & Std Error Mean \\
\hline \multirow{2}{*}{ Pair } & Pre test scores & 79.38 & 16 & 13.022 & 3.256 \\
& Post test scores & 84.38 & 16 & 13.150 & 3.287 \\
\hline
\end{tabular}

The data from the table above shows that the result of the average pretest score is 79.38 while the posttest average score is 84.38 . The results of the two pretest and posttest values show that the posttest value is higher than the pretest value. In the next step, before testing the hypothesis to determine the results of students' mathematical reasoning abilities, the researchers first conducted a normality test.

\section{Normality test}

The normality test used in this study is the Kolmogorov-Smirnov on SPSS version 17. After performing the Kolmogorov-Smirnov normality test, the interpretation with the applicable terms and conditions can be seen. The following are the data analysis results, namely.

TABLE 2. Kolmogorov-Smirnov normality test

\begin{tabular}{clcccccc}
\hline & Group & \multicolumn{3}{c}{ Kolmogorov-Smirnov } & \multicolumn{3}{c}{ Shapiro-Wilk } \\
\cline { 3 - 7 } & & Statistic & df & Sig & Statistic & df & Sig \\
\hline \multirow{2}{*}{ Scores } & Pre test scores & 145 & 16 & 200 & 950 & 16 & 483 \\
& Post test scores & 195 & 16 & 105 & 883 & 16 & 483 \\
\hline
\end{tabular}

a. Liliefors Significance Correction

* This is lower bound of the true significance

The research data shows that the pretest significance level in the Kolmogorov Smirnov table is $0.200>0.05$, while the posttest significant level in the KolmogorovSmirnov table is $0.105>0.05$. So it can be concluded that the data is normally distributed. After conducting the normality test, it was followed by a reliability test to determine the accuracy of the instrument used. 


\section{Reliability Test}

The terms and conditions that apply to this reliability test are that if the data value is $>$ 0.05 , it can be reliable, whereas if the data is $<0.05$, it is said to be unreliable. Table 3 below shows the data from the reliability test.

TABLE 3. Reliability test

\begin{tabular}{cc}
\hline Cronbac's Alpha & N of items \\
\hline 661 & 2 \\
\hline
\end{tabular}

Based on table 3 above, that reliability can be seen through Cronbach's alpha table, which shows the number 0.661 . It means $>0.05$ so that the data can be declared reliable or appropriate to use. Furthermore, hypothesis testing is carried out.

\section{Hypothesis Testing}

Hypothesis testing is the essence of processing data, where this test is carried out to answer the problem formulation by knowing whether or not there is an effect of the treatment given. When viewed from the average results of the pretest and posttest, descriptively, there are differences in the average results. However, to determine whether the difference is significant or not, it is necessary to conduct a paired sample t-test. The results of the paired sample t-test are as follows:

Table 4 Output "Paired Sample Test"

\begin{tabular}{|c|c|c|c|c|c|c|c|c|c|}
\hline \multicolumn{9}{|c|}{ Paired Differences } & \multirow{3}{*}{$\begin{array}{l}\text { Sig. (2- } \\
\text { tailed) }\end{array}$} \\
\hline & & \multirow[b]{2}{*}{ Mean } & \multirow{2}{*}{$\begin{array}{c}\text { Sts } \\
\text { Deviation }\end{array}$} & \multirow{2}{*}{$\begin{array}{l}\text { Std. } \\
\text { Error } \\
\text { Mean }\end{array}$} & \multicolumn{2}{|c|}{$\begin{array}{l}95 \% \text { Confidence } \\
\text { Interval of the } \\
\text { Difference }\end{array}$} & \multirow[t]{2}{*}{$\mathrm{t}$} & \multirow[t]{2}{*}{$\mathrm{df}$} & \\
\hline & & & & & Lower & Upper & & & \\
\hline Part 1 & $\begin{array}{l}\text { Pre test } \\
\text { scores } \\
\text { Post test } \\
\text { scores }\end{array}$ & -5.000 & 13.166 & 3.291 & -12.015 & 2.015 & -1.519 & 15 & -150 \\
\hline
\end{tabular}

Based on the table in the research results, it can be seen that the value of sig. (2tailed) is 0.150. According to (Sugiyono, 2014) decision-making data analysis is based on probability if $<0.05$, then $\mathrm{HO}$ is rejected, and if $>0.05$, then $\mathrm{H} 1$ is accepted. So it can be concluded that if the value of sig. (2-tailed) is $0.150>0.05$, then H1 is accepted. This means that the RME approach has a positive and significant influence on students' reasoning abilities. The results of the calculation of the pretest and posttest scores, among others, can be explained based on figure 1 below.

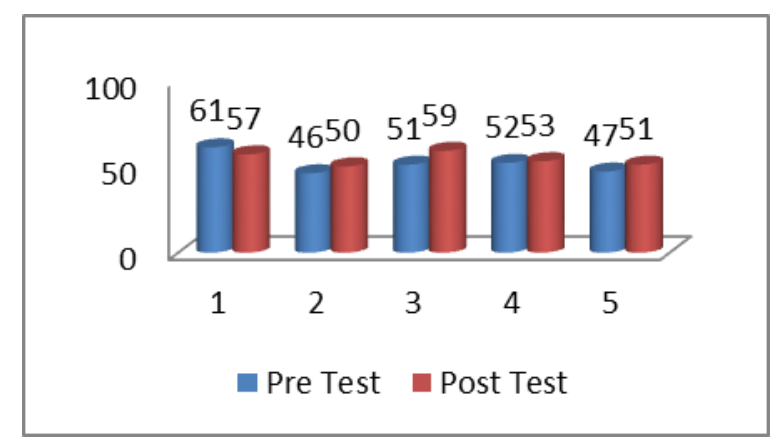

DIAGRAM 1. Pretest and posttest results 
The graph above shows that four-question indicators have increased, and the onequestion indicator has decreased. The indicator that has decreased is the indicator in question number 1 about the ability of students to present mathematical statements in the form of pictures.

\section{DISCUSSION}

From research results, students who have a good level of understanding can present statements in the form of pictures correctly, but some of the students who have low understanding abilities have difficulty solving the problems given. In this case, before students can present the correct answer. Students must coordinate various representations to get the proper guidance in understanding the correct concept (M. Doorman et al., 2012; Ekowati \& Suwandayani, 2020; Rudi et al., 2020). It needs to be supported as a facilitator and role model in learning. Teachers must appear perfect in teaching concepts correctly (Ulia \& Kusmaryono, 2021). What if the teacher cannot provide and deliver the correct concept to students? Of course, this is a challenge in itself in education.

Furthermore, the indicator of question number 2 is about the ability of students to manipulate mathematics. In this indicator, students can carry out mathematical manipulation well by converting story problems into mathematical sentences and changing length units from $\mathrm{cm} 2$ to $\mathrm{m} 2$ units, and vice versa. In learning mathematics that uses RME, students learn by using realistic media (Herman et al., 2019; Noviani et al., 2017; Sutisna \& Subarjah, 2016). In this case, realistic media adds confidence to a student in learning mathematics. When teachers build these beliefs well, it is easy for students to use them in developing mathematics learning (Tamba \& Cendana, 2021).

Indicator question number 3 is regarding students' ability to compile and provide evidence of the correctness of the solution. If seen in the diagram above, the indicator for question number 3 has increased significantly compared to other indicators. In this indicator, students can compile evidence by correctly obtaining the area of the triangular shape of the roof of a house and proving that there is an area of land that is not used for gardening. Thus, students can fulfill their ability in compiling evidence by writing down the methods used to solve problems correctly and adequately. One of the keys to reaching this stage is the correct understanding of the concept. Understanding mathematical concepts is a complex question regarding teachers, students, and other supporting components in learning (Godino et al., 2011). Therefore, there is still a lot of research space in learning mathematics (Björklund et al., 2020).

The indicator of question number 4 is about the ability of students to conclude a statement. This indicator also increased but not significantly. In this case, students can conclude from mathematical statements obtained from their work questions. The final results are obtained from students who can formulate questions well and solve problems correctly. After all, can be completed coherently, students will be able to conclude what is asked in the question. The indicator of the ability to find patterns or traits to make generalizations is found in question number 5 . The ability of students to make generalizations can be made well. It can be seen from students who can determine a pattern to get a formula from a square shape. Thus, students can achieve the goals of the indicator questions themselves (Strand \& Mills, 2014).

Based on the above description, the increase in students' reasoning abilities can be influenced by several factors, including the RME approach. Realistic mathematics learning is based on learning by utilizing realistic media so that it is close to experiences or activities in the daily lives of students (Fuadiah, 2013; Laurens et al., 2018; Obiarta et al., 2014). Moreover, it can help students not feel burdened when learning because, at the time of learning, students can directly imagine or see objects around which are the learning material. In addition, the implementation of learning using video becomes the attraction of students so that learning is more fun. However, it is feared that the 
implementation of learning can lead to a lack of achievement of a learning goal because there is no direct interaction between teachers and students. It can be proven by the presence of indicators that have not been achieved.

Based on diagram 1, information is also obtained, that the most significant increase in the pretest-posttest scores lies in indicators 2 and 5. Indicator 2 is the ability of students to perform mathematical manipulation. While indicator 5 , namely the ability of students to make generalizations, can be done well. At this stage, students can convert story problems into mathematical sentences. These two indicators, which are part of the students' reasoning abilities, prove the opinion of Gravemeijer (1994: 91) (Fuadiah, 2013) which states that there are three main principles of practical mathematics learning, namely as follows: (1) Guided reinvention and didactical phenomenology, guided reinvention. That in mathematics, all students have the same opportunity. Where at that time the mathematical process can be found, (2) progressive mathematization, meaning that the problems presented in mathematics learning come from the actual situations and conditions of students before students can reach the level of formal mathematics, and (3) self-developed models, used as bridges for students in connecting real situations with concrete situations. It is called the situation of connecting informal mathematics with formal mathematics (L. M. Doorman \& Gravemeijer, 2009; Drijvers et al., 2010; Laurens et al., 2018; Noviani et al., 2017).

\section{CONCLUSION}

In conclusion, learning to find with the RME approach begins with understanding contextual problems, solving questions, comparing answers to these questions, and drawing conclusions from the problems given. Learning that is carried out not far from students' experience can make it easier for students to absorb the knowledge given. Students feel happier and better understand learning by using the objects around them. So that the learning made becomes more meaningful. It can be underlined that there is a positive and significant effect of the Realistic Mathematics Education (RME) approach on students' reasoning abilities in the fourth grade flat plane of SD Muhammadiyah 3 Assalam Malang. Among the five indicators of students' reasoning ability, there is a second indicator, and the fifth one has a more significant improvement than other indicators, namely Indicator 2 is the ability of students to perform mathematical manipulation. While indicator 5, namely the ability of students to make generalizations, can be done well. Therefore, it is suggested to increase the application of the RME approach for elementary students so that other math skills can be improved and provide meaningful learning for elementary students.

\section{REFERENCES}

1. Arsaythamby, V., \& Zubainur, C. M. (2014). How a Realistic Mathematics Educational Approach Affect Students' Activities in Primary Schools? Procedia - Social and Behavioral Sciences, 159, 309-313. https://doi.org/10.1016/j.sbspro.2014.12.378

2. Basori, E. R. (2018). Pengaruh Pembelajaran Matematika Realistik terhadap Kemampuan Berhitung Anak Tunagrahita Ringan Kelas 1 di SD Inklusi Glagahwero 01. Journal of Special Education, I(2), 1-4.

3. Björklund, C., van den Heuvel-Panhuizen, M., \& Kullberg, A. (2020). Research on early childhood mathematics teaching and learning. ZDM - Mathematics Education, 52(4), 607-619. https://doi.org/10.1007/s11858-020-01177-3

4. Burais, L., Ikhsan, M., \& Duskri, M. (2016). Peningkatan Kemampuan Penalaran Matematis Siswa melalui Model Discovery Learning. Jurnal Didaktik Matematika, 3(1), 77-86. https://doi.org/10.24815/jdm.v3i1.4639

5. Creswell, J. W., \& Clark, V. L. P. (2018a). Designing and conducting mixed methods research approarch. 849. 
6. Creswell, J. W., \& Clark, V. L. P. (2018b). Praise for the Third Edition.

7. Doorman, L. M., \& Gravemeijer, K. P. E. (2009). Emergent modeling: Discrete graphs to support the understanding of change and velocity. ZDM - International Journal on Mathematics Education, 41(1-2), 199-211. https://doi.org/10.1007/s11858-0080130-z

8. Doorman, M., Drijvers, P., Gravemeijer, K., Boon, P., \& Reed, H. (2012). Tool use and the development of the function concept: From repeated calculations to functional thinking. International Journal of Science and Mathematics Education, 10(6), 12431267. https://doi.org/10.1007/s10763-012-9329-0

9. Drijvers, P., Doorman, M., Boon, P., Reed, H., \& Gravemeijer, K. (2010). The teacher and the tool: Instrumental orchestrations in the technology-rich mathematics classroom. Educational Studies in Mathematics, 75(2), 213-234. https://doi.org/10.1007/s10649-010-9254-5

10. Ekowati, D. W. (2017). The Mathematical Connection Ability in Multiplication Material at Elementary School. In The Social Sciences (Vol. 12, Issue 12, pp. 2212-2217).

11. Ekowati, D. W., Kusumaningtyas, D. I., \& Sulistyani, N. (2017). Ethnomathematica Dalam Pembelajaran Matematika (Pembelajaran Bilangan Dengan Media Batik Madura, Tari Khas Trenggal Dan Tari Khas Madura). Jurnal Pemikiran Dan $\begin{array}{lllll}\text { Pengembangan Sekolah Dasar } & 716 .\end{array}$ https://doi.org/10.22219/jp2sd.vol5.no2.716-721

12. Ekowati, D. W., \& Suwandayani, B. I. (2020). Understanding the Concept of Ï€ Numbers for Elementary School Pre-Service Teachers on Circle Materials. Jurnal Prima Edukasia, 8(1), 12-19. https://doi.org/10.21831/jpe.v8i1.30103

13. Firmanti, P. (2017). Penalaran Siswa Laki-laki dan Perempuan dalam Proses Pembelajaran Matematika. HUMANISMA: Journal of Gender Studies, 1(2), 73-85.

14. Fuadi, R., Johar, R., \& Munzir, S. (2016). Peningkatkan Kemampuan Pemahaman dan Penalaran Matematis melalui Pendekatan Kontekstual. Jurnal Didaktik Matematika, 3(1), 47-54. https://doi.org/10.24815/jdm.v3i1.4305

15. Fuadiah, N. F. (2013). Design of Teaching Materials Based on Realistic Mathematic Education (RME) to Improve Students Creative Thinking Ability. Proceeding The First South East Asia Design/Development Research (SEA-DR) International Conference, 299-305. http://eprints.unsri.ac.id/2438/1/P35_Nyiayu_F_305.pdf

16. Godino, J. D., Font, V., Wilhelmi, M. R., \& Lurduy, O. (2011). Why is the learning of elementary arithmetic concepts difficult? Semiotic tools for understanding the nature of mathematical objects. Educational Studies in Mathematics, 77(2-3), 247-265. https://doi.org/10.1007/s10649-010-9278-x

17. Gusmida, R., \& Islami, N. (2017). The Development of Learning Media for the Kinetic Theory of Gases Using the ADDIE Model with Augmented Reality. Journal of Educational Sciences, 1(1), 1. https://doi.org/10.31258/jes.1.1.p.1-10

18. Habibatul Izzah, K., \& Azizah, M. (2019). Analisis Kemampuan Penalaran Siswa Dalam Pemecahan Masalah Matematika Siswa Kelas Iv. Indonesian Journal Of Educational Research and Review, 2(2), 210. https://doi.org/10.23887/ijerr.v2i2.17629

19. Herman, M., Arnawa, I. M., \& Ardipal, A. (2019). The Effect of Realistic Mathematic Education (RME) toward Motivation and Learning Achievement of the Fourth Grade Elementary Students. 178(ICoIE 2018), 508-511. https://doi.org/10.2991/icoie18.2019.109

20. Hidayati, K. N. (2013). Peningkatan Kemampuan Penalaran Matematika Siswa Melalui Model Pembelajaran Learning Cycle "5-E" Dengan Menggunakan Alat Peraga Pada Siswa Kelas V Sd N 03 Mudal Boyolali Tahun Ajaran 2012/2013. Repositori Universitas Muhammadiyah Surakarta.

21. Holisin, I. (2009). Melatih Penalaran Siswa Sekolah Dasar Dalam Memahami Konsep Bilangan Pecahan Dan Menyelesaikan Masalah Penjumlahan Dan Pengurangan Bilangan Pecahan. Didaktis, 8(3), 20-33.

22. Karabulut, A., \& Özmen, E. R. (2018). Effect of "understand and solve!" strategy 
instruction on mathematical problem solving of students with mild intellectual disabilities. International Electronic Journal of Elementary Education, 11(2), 77-90. https://doi.org/10.26822/iejee.2018245314

23. Laurens, T., Batlolona, F. A., Batlolona, J. R., \& Leasa, M. (2018). How does realistic mathematics education (RME) improve students' mathematics cognitive achievement? Eurasia Journal of Mathematics, Science and Technology Education, 14(2), 569-578. https://doi.org/10.12973/ejmste/76959

24. Malik, A. (2014). Fungsi Komunikasi Antara Guru dan Siswa dalam Meningkatkan Kualitas Pendidikan (Studi Kasus Proses Belajar Mengajar pada SMP Negeri 3 Sindue). INTERAKSI: Jurnal IImu Komunikasi, 3(2), 168-173. https://doi.org/10.14710/interaksi,3,2,168-173

25. Nashihah, D., Sulianto, J., \& Asri Untari, M. F. (2019). Klasifikasi Kemampuan Penalaran Matematis Siswa Kelas Iv Sd Negeri Tambakrejo 02 Semarang. Indonesian Journal of Educational Research and Review, 2(2), 203. https://doi.org/10.23887/ijerr.v2i2.17628

26. Nasongo, J. W., Majanga, E. K., \& Sylvia, V. K. (2011). The Effect of Class Size on Classroom Interaction During Mathematics Discourse in the Wake of Free Primary Education: A Study of Public Primary Schools in Nakuru Municipality. Current Research Journal of Social Sciences, 3(1), 44-49. http://maxwellsci.com/print/crjss/v3-44-49.pdf

27. Noviani, J., Syahputra, E., \& Abdul Murad. (2017). The Effect of Realistic Mathematic Education ( RME ) in Improving Primary School Students ' Spatial Ability in Subtopic Two Dimension Shape. Journal of Education and Practice, 8(34), 112-126.

28. Obiarta, I., Sudiana, I., \& Rasana, I. (2014). Penerapan Pendekatan Rme (Realistic Mathematic Education) Untuk Meningkatkan Hasil Belajar Matematika. Jurnal Mimbar PGSD Universitas Pendidikan Ganesha, 2(1), 22-45.

29. Pane, A., \& Darwis Dasopang, M. (2017). Belajar Dan Pembelajaran. FITRAH:Jurnal Kajian Ilmu-Ilmu Keislaman, 3(2), 333. https://doi.org/10.24952/fitrah.v3i2.945

30. Roqib. (2019). Ilmu Pendidikan Islam; Pengembangan Pendidikan Integratif di Sekolah, Keluarga, dan Masyarakat.

31. Rudi, R., Suryadi, D., \& Rosjanuardi, R. (2020). Identifying Students' Difficulties in Understanding and Applying Pythagorean Theorem With an Onto-Semiotic Approach. MaPan, 8(1), 1-18. https://doi.org/10.24252/mapan.2020v8n1a1

32. Saleh, M., Charitas, R., Prahmana, I., \& Isa, M. (2018). Improving the Reasoning Ability of Elementary School Student Through the Indonesian Realistic. Journal on Mathematics Education, 9(1), 41-54.

33. Siagian, M. D. (2016). Kemampuan koneksi matematik dalam pembelajaran matematika. MES: Journal of Matematics Education and Science2, 2(1), 58-67.

34. Strand, K., \& Mills, B. (2014). Mathematical content knowledge for teaching elementary mathematics: A focus on algebra. Mathematics Enthusiast, 11(2), 385-432.

35. Sugiyono. (2014). prof. Dr. Sugiyono, Metode Penelitian Pendidikan, pendekatan kuantitatif. intro (PDFDrive).pdf.

36. Sugiyono, \& Republik Indonesia. (2010). Metode Penelitian Kuantitatif \& kualitatif. In Journal of Experimental Psychology: General.

37. Sutisna, A. P., \& Subarjah, H. (2016). Meningkatkan Pemahaman Matematis Melalui Pendekatan Tematik Dengan Rme. Jurnal Pena Ilmiah, 1(1), 31-40. https://doi.org/10.23819/pi.v1i1.2929

38. Tamba, K. P., \& Cendana, W. (2021). The Relationship between pre-service elementary school mathematics teachers' beliefs about epistemology of mathematics, teaching and learning, and mathematics assessment. Premiere Educandum : Jurnal Pendidikan Dasar Dan Pembelajaran, 11(1), 40. https://doi.org/10.25273/pe.v11i1.8311

39. Ulia, N., \& Kusmaryono, I. (2021). Mathematical Disposition of Students', Teachers, and Parents in Distance Learning: A Survey. Premiere Educandum : Jurnal Pendidikan Dasar Dan Pembelajaran, 11(1), 147. https://doi.org/10.25273/pe.v11i1.8869 
40. Wood, L. N. (2012). Practice and conceptions: Communicating mathematics in the workplace. Educational Studies in Mathematics, 79(1), 109-125. https://doi.org/10.1007/s10649-011-9340-3

\section{PROFILE}

Dyah Worowirastri Ekowati is a lecturer at the Elementary School Teacher Education Study Program, Teacher Training and Education Faculty, University of Muhammadiyah Malang. Apart from serving as editor in chief of the Journal of Elementary School Thought and Development. Author 1 is also active in research activities in the field of mathematics learning

Figa Zulfi Azzaha, namely alumni of the Elementary School Teacher Education Study Program, Faculty of Teacher Training and Education, University of Muhammadiyah Malang.

Setiya Yunus Saputra is a lecturer in the Elementary School Teacher Education Study Program, Teacher Training and Education Faculty, University of Muhammadiyah Malang.

Beti Istanti Suwandayani is also a lecturer at the Elementary School Teacher Education Study Program, Faculty of Teacher Training and Education, University of Muhammadiyah Malang. He is also the editor of the Journal of Primary School Thought and Development. In addition, he is active in research projects in the field of basic education. 